\title{
Sie \\ First report of Itersonilia perplexans on Heracleum sosnowskyi in Russia
}

\author{
E.L. Gasich, I.A. Kazartsev, L.B. Khlopunova, N.S. Pilshchikova and Ph.B. Gannibal*
}

All-Russian Institute of Plant Protection, shosse Podbelskogo 3, 196608 Saint Petersburg, Russia

*E-mail: phbgannibal@yandex.ru

Received: 02 May 2013. Published: 23 Feb 2014. Keywords: Sosnowsky's hogweed, fungal plant disease

Sosnowsky's hogweed (Heracleum sosnowskyi; Apiaceae) is cultivated as a forage plant. However, in some regions it appears as a weed dangerous for human health. Over the period July-August 2008, individual $H$. sosnowskyi plants with vigorous blight symptoms (Fig. 1) were observed in two places (35 km apart) in the Leningrad region of northwestern Russia. Diseased plants had brown or orange-brown spots on leaves (Fig. 2). On some leaves the spots coalesced to form large necrotic areas in the leaf centre or on the margin.

The pathogen was isolated by fixing sections of surface-sterilised diseased leaves onto petri dish lids with Vaseline ${ }^{\circledR}$ over potato sucrose agar (PSA) After two week's incubation on PSA at $24^{\circ} \mathrm{C}$, colonies that were pale cream in colour and velvety with feathery margins reached $27.2 \mathrm{~mm}$ in diameter. Mycelium was hyaline with clamp connections at the septa. Swelling sporogenous cells were intercalary or terminal, pyriform, ovoid to subglobose. Sporogenous cells germinated with hyphae or sterigmata, on which ballistospores formed. Ballistospores were hyaline, broadly-lunate to pyriform, (11-)16.6(-22) x (8-)12.2(-18.5) um (Fig. 3). Globose chlamydospores were solitary or in clusters, 8.9-11.7 $\mu \mathrm{m}$ in size. Based upon these morphological characteristics, the fungus was identified as Itersonilia perplexans. This identification was confirmed by comparison of internal transcribed spacer (ITS) sequence data with GenBank data. The ITS1-5.8S-ITS2 region of rDNA was amplified by polymerase chain reaction (PCR) and sequenced. BLAST analysis revealed the highes identity of our 595 bp sequence (GenBank Accession No. KF780585) with that of I. perplexans ex-type strain CBS 363.85 (NR077117). The only difference between the sequences was a substitution at one site.

Pathogenicity of the fungus was confirmed by inoculating leaf discs and whole plants. The fungus was cultivated on PSA for two weeks. Ballistospores were collected by rinsing the agar culture with $5 \mathrm{ml}$ of sterile water with $0.01 \%$ Tween-60. Drops $(10 \mu \mathrm{l})$ of the suspension (1x10ballistospores $/ \mathrm{ml})$ were put on 12 leaf discs placed in petri dishes on wet filter paper (Fig. 4). Six whole plants were inoculated by spraying the suspension $\left(1 \times 10^{6}\right.$ ballistospores $\left./ \mathrm{ml}\right)$ of the fungus until run-off. Control plants were sprayed with water only. All plants were incubated for 48 hours at $100 \%$ humidity at $22-24^{\circ} \mathrm{C}$ and then kept on a laboratory bench Symptoms appeared three days after inoculation on the inoculated plants, whereas the control plants remained symptomless. After seven days, the average percentage of the necrotic area was $65 \%$. The pathogen was reisolated as described above confirming Koch's postulates. I. perplexans is reported to cause flower blight and other symptoms on some other species in the Asteraceae and Apiaceae, recorded in European and Asian countries, North America, Australia and New Zealand (Channon, 1963; Boekhout et al., 1991; Seijo et al., 2000; Koike \& Tjosvold, 2001; McGovern et al., 2006; Rodeva et al., 2009). This is the first report of I. perplexans on $H$. sosnowskyi in Russia. This fungus has potential as a biocontrol agent for this noxious weed

\section{Acknowledgements}

This work was supported by Russian Ministry for Education and Science (contract \# 14.518.11.7067)

\section{References}

Boekhout T, Poot G, Hackman P, 1991. Genomic characteristics of strains of Itersonilia: taxonomic consequences and life cycle. Canadian Journal of Microbiology 37, 188-194. http://dx.doi.org/10.1139/m91-029

Channon AG, 1963. Studies on parsnip canker. I. The causes of the disease Annals of Applied Biology 51, 1-15. http://dx.doi.org/10.1111/j.1744-7348.1963.tb03670.x

Koike ST, Tjosvold SA, 2001. A blight disease of dill in California caused by Itersonilia perplexans. Plant Disease $\mathbf{8 5}, 802$. http://dx.doi.org/10.1094/PDIS.2001.85.7.802B

McGovern RJ, Horita H, Stiles CM, Seijo TE, 2006. Host range of Itersonilia perplexans and management of Itersonilia petal blight of China aster. Plant Health Progress [http://www.plantmanagementnetwork.org/php/ elements/sum.aspx $? \mathrm{id}=5640 \&$ photo $=3235]$ http://dx.doi.org/10.1094/PHP-2006-1018-02-RS

Rodeva R, Gabler J, Stoyanova Z, 2009. First evidence of Itersonilia perplexans on dill (Anethum graveolens) in Bulgaria. Sodininkyste ir daržininkystè 28, 193-198.

Seijo TE. McGovern RJ, Marenco de Blandino A, 2000. Petal blight of sunflower caused by Itersonilia perplexans. Plant Disease 84, 1153 http://dx.doi.org/10.1094/PDIS.2000.84.10.1153B

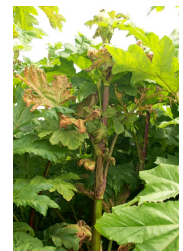

Figure

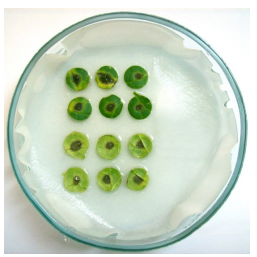

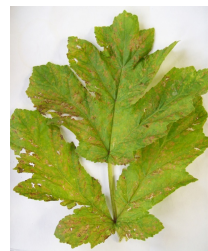

Figure 2

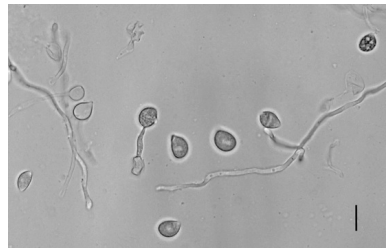

Figure 3

Figure 4

To cite this report: Gasich EL, Kazartsev IA, Khlopunova LB, Pilshchikova NS, Gannibal PB, 2014. First report of Itersonilia perplexans on Heracleum sosnowskyi in Russia. New Disease Reports 29, 6. http://dx.doi.org/10.5197/j.2044-0588.2014.029.006 